AL IBTIDA: JURNAL PENDIDIKAN GURU MI (2019) Vol 6 (2): 271-285

DOI: http://dx.doi.org/ 10.24235/al.ibtida.snj.v6i2.5149

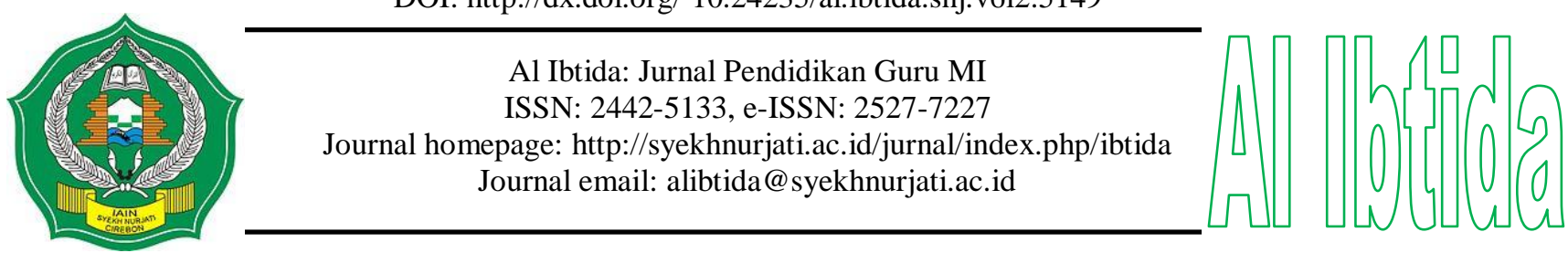

\title{
The Effectiveness of Google Classroom Media on the Students' Learning Outcomes of Madrasah Ibtidaiyah Teacher Education Department
}

\author{
Fauzan* \\ *Department of Madrasah Ibtidaiyah Teacher Education, Faculty of Tarbiyah and Teacher Training, \\ UIN Syarif Hidayatullah Jakarta \\ Email: fauzan@uinjkt.ac.id \\ Fatkhul Arifin** \\ **Department of Madrasah Ibtidaiyah Teacher Education, Faculty of Tarbiyah and Teacher Training, \\ UIN Syarif Hidayatullah Jakarta \\ Email: fatkhul_arf@uinjkt.ac.id
}

Received: September 06 ${ }^{\text {th }}, 2019$. Accepted: October 03 ${ }^{\text {th }}, 2019$. Published: October $29^{\text {th }}, 2019$.

\begin{abstract}
This study aims to determine the effectiveness of the use of google classroom media on students' learning outcomes at Madrasah Ibtidaiyah Teacher Education Department of UIN Syarif Hidayatullah Jakarta. The research adopts qualitative method, which examines students' learning outcomes using google classroom media, where researchers apply the media during learning instruction. Data collection techniques used were students' learning outcomes, in-depth interviews, and documentation. Data analysis using interactive models and testing the validity of data using tests of credibility (internal validity), transferability (external validity), dependability (reliability), and cconformability (objectivity). The results showed that the use of google classroom media was effective in improving the students' learning outcomes of Madrasah Ibtidaiyah Teacher Education Department of UIN Syarif Hidayatullah Jakarta. Therefore, the use of google classroom media can be used as an alternative media in the learning process.
\end{abstract}

Keywords: google classroom media, e-learning, learning outcomes.

\begin{abstract}
Abstrak
Penelitian ini bertujuan untuk menentukan efektivitas penggunaan media google clasroom terhadap hasil belajar mahasiswa jurusan Pendidikan Guru Madrasah Ibtidaiyah UIN Syarif Hidayatullah Jakarta. Metode penelitian yang digunakan adalah metode kaulitatif, yakni menelaah hasil belajar mahasiswa yang menggunakan media google classroom, di mana peneliti menerapkan media tersebut pada saat pembelajaran. Teknik pengumpulan data yang digunakan adalah hasil belajar mahasiswa, wawancara mendalam dan dokumentasi. Analisis data menggunakan model interaktif dan pengujian keabsahan data menggunakan uji credibility (validitas internal), transferability (validitas eksternal), dependability (reliabilitas), dan Confirmability (objektivitas). Hasil penelitian menunjukkan bahwa penggunaan media google classroom efektif dalam meningkatkan hasil belajar mahasiswa jurusan Pendidikan Guru Madrasah Ibtidaiyah UIN Syarif Hidayatullah
\end{abstract}


Jakarta. Oleh karena itu, penggunaan media google classroom dapat dijadikan sebagai media alternative dalam proses pembelajaran.

Kata kunci: media google classroom, e-learning, hasil belajar.

\section{INTRODUCTION}

Education is the government's effort to improve the life of the nation. The more citizens who are educated the country should be more advanced, increasing poverty will be increasingly reduced. In-Law No. 20/2003 Article 1 Paragraph 1 it has been stated that Education is a conscious and planned effort to create a learning atmosphere and learning process so that students actively develop their potential to have religious-spiritual strength, self-control, personality, intelligence, morals noble, as well as the skills needed by himself, society, nation, and state (Law No.20, 2003). This means that education aims to make people have the ability of soft skills and hard skills, where later these abilities will become provisions for them in the future.

Education cannot be separated from the education process itself. The process in education itself is commonly known as learning. Learning is a process of interaction between students and educators and learning resources in a learning environment. This means that in addition to the role of educators, what can't be separated is the use of media as a conveyor of material between educators and students. With the media, of course, the learning process will be more effective.

Effectiveness in learning is very important, this is very influential on the process and learning outcomes. Miarso in Rohmawati (2015) said that the effectiveness of learning is one of the quality standards of education and is often measured by the achievement of objectives, or can also be interpreted as accuracy in managing a situation, doing the right things. If we see the world of our students, the effectiveness of learning can be achieved if using media aids, in this study researchers used online media as a supporting tool in the learning process. From the above understanding, there are several criteria for learning effectiveness, including: (1) the ability of teachers to manage learning well; (2) student activities in good learning; (3) student learning outcomes are completed classically (Susilo, 2013).

There are several criteria for assessing the effectiveness of learning media. Hubbard in Badriyah (2015) suggested that there were at least nine criteria. The first is related to financing. If we look at the first criteria, then learning to use online media is very supportive, because in addition to inexpensive online media is also effective because it can be accessed anywhere and anytime. The next criterion is the availability of supporting facilities such as electricity, appropriate class size, effectiveness, and ability to change, time and energy in preparation, the 
effects, difficulties and finally the benefits. The more learning objectives that can be helped with a media the better the media. From these two criteria, the use of online electronic media used by researchers is very suitable, because it is very economical and practical.

In the current era of globalization, learning is characterized by-products and the use of information technology that is very fast, the concept in the implementation of learning has moved on efforts to embody increasingly modern learning. The characteristics of modern here have previously been achieved in the development of education and learning, but all of them are still in the stage of software intelligence.

Learning theory has been developed by several figures, such as Pavlov \& Gantt (1941), Skinner (1950), Ausubel (1967), Gagne (1968), Bloom (1973) who discovered patterns of thinking in conditioning human learning. Nevertheless, human sensitivity does not always exist, therefore learning and learning concepts are born that try to integrate the intelligence software product into its hardware intelligence component that developed after Heinich (1984), Couse \& Chen (2010), Walter \& Briggs (2012), Seels \& Rachey (2012) developed the concept of learning technology.

The concept of educational technology is still focused on efforts to give birth to the procedures for solving these problems. The concept has been found that is innovation in learning models based on information technology. One of them is animation learning, learning games, computer-based learning tutorial (Kurnia, Darmawan, \& Maskur, 2018).

A hot issue that is currently developing is learning in the industrial era 4.0. In this era, educators are required not only to have skills in teaching but also to be skilled in using learning media. In this era, several aspects must be mastered by educators, including mastery of internet technology. The internet has become an effective and efficient part of getting and exchanging data and information without looking at the dimensions of space and time. The development of internet technology today affects various aspects of life, including aspects of government, economic, social, to education.

Modernization of technology has not only penetrated the world of commerce, but technology has begun to penetrate the world of education. The education world has begun to leave learning offline. The world of education today has begun to lead to learning that leads to online learning (Gunawan, 2017). In the world of education, the use of the internet has become one of the alternative learning methods that can be used, one of which is the use of electronic learning or commonly engulfed by the term e-learning. E-learning is a form of learning model that is facilitated and supported by the use of information and communication technology (Hanum, 2013). E-learning is the basis and logical consequence of the development of information and communication technology. E-learning is a generic term for all technologically 
supported learning using an array of teaching and learning tools as phone bridging, audio and videotapes, teleconferencing, satellite transmissions, and the more recognized web-based training or computer-aided instruction also known referred to as (Kusmana, 2011). Alonso, López, Manrique, \& Viñes (2005) argues that E-learning is defined as the use of new multimedia technologies and the Internet to improve the quality of learning by facilitating access to resources and services, as well as remote exchange and collaboration, such learning technology can also be called web-based learning (Web-Based Instruction).

Another opinion expressed by Cisco in Yazdi (2012), that e-learning has several philosophies, including first, e-learning is a way of conveying information, communication, education, training online. The first, way that we can be familiar with the term online, teacher professional education program (PPG) uses this method before the implementation of face-toface learning. Second, e-learning provides a set of tools that can add value to students in conventional learning, so that they can answer the challenges of globalization that are increasingly developing. This is the challenge of learning in the industrial era 4.0, that not only teachers must be technology literate but students must also be introduced as early as possible. Third, e-learning does not mean shifting the classical learning model (conventional) in the classroom, but e-learning here is expected to improve the learning model through enrichment / additional tasks on the contents of the material and the development of educational technology. Fourth, the ability of students varies depending on the contents of the material and how it is delivered. The better the balance between parts and media with learning styles, the better the students' abilities in good learning outcomes. Research examining the effectiveness of e-learning has increased in recent years (Signe \& Rikke, 2015).

This is mainly due to the increase in IT in learning, however, e-learning learning cannot be separated from conventional learning. Based on the opinions of some of the experts above it can be concluded that e-learning is a learning model that utilizes internet technology, in practice this online learning can be done anywhere and anytime by the characteristics of interactive, effective, independent, easily accessible, and enables the enrichment of technology use. Suharyanto \& Mailangkay (2016) said that by using the e-learning method, lecturers can increase the intensity of interactive communication with students outside the official lecture schedule.

The e-learning method gives the lecturer the freedom to give away / access to students to obtain scientific references related to the subject that is not obtained during the lecture. All references in the form of scientific writings, popular articles or electronic journals can be given through e-learning media. This is very useful for students, in addition to being able to strengthen understanding for each subject of lectures, references from international journals will be very helpful in broadening student insights while increasing English language skills. According to 
Slavin in Zakaria \& Salleh (2012), the effectiveness of learning can be measured using 4 (four) indicators: 1) The quality of learning (quality of insurance), i.e. how much is the level of information provided so that students can easily learn it and the level of error will be small make. 2) Appropriate level of instruction, the extent to which the teacher ensures the level of readiness of students in accepting new material. 3) Incentives, how much effort the teacher motivates students to complete or do the tasks and study the material provided; and 4) time, time needed to complete learning activities. Therefore, the more active students are in learning, the more effective learning is carried out. Although google classroom has quite complete features, unfortunately until now there are still many teachers at the school who do not know about google classroom (Soni, Hafid, Hayami, Fatma, Wenando, Al Amien, \& Hasanuddin, 2018).

The use of online electronic media has been widely developed by researchers and has been widely tested, including the moodle, Edmodo and google classroom programs. Of course, various media have advantages and disadvantages. In this research, the media that we want to examine is the use of google classroom, because google classroom is a medium that is quite effective in learning. Existing programs allow anyone to use it. Google Classroom is a mixed learning model that is used for every scope of education which aims as a solution to the difficulties in creating, sharing and grouping assignments without having to collect paperless assignments. Google Classroom is designed to facilitate the interaction of lecturers or teachers with students or students in cyberspace. This application provides an opportunity for lecturers or teachers to explore the scientific ideas they have to students or students (Rozak \& Albantani, 2018). This software has been published to the world community as part of Google Apps for Education (GAFE) since August 12, 2014. This application makes it easy for educators and students to carry out the learning process. In use, educators and students can collect, give, and assess assignments without being bound by time limits. Google Classroom is used to help educators create and collect assignments without having to type or use paper (paperless), including features that can make time effects such as the ability to automatically make copies of documents for each student.

This electronic class can also create a folder to store every assignment outside the teacher and each student who sends the assignment so that the file/assignment that is sent is not scattered and kept organized. Students can track each assignment that is almost close to the deadline for collection on the assignment page, and start working on it with just one click. Teachers can quickly see who hasn't finished an assignment, and provide direct input and grades in electronic classes. Through the Google Classroom application, it is assumed that learning objectives will be more easily realized and full of meaningfulness. Therefore, the use of Google Classroom actually makes it easier for teachers to manage to learn and convey information precisely and 
accurately to students (Hardiyana, 2015). Through learning with blended learning, students feel comfortable and active in constructing their knowledge. Teachers can take advantage of various features found in Google Classroom such as assignments, grading, communication, time-costs, archive courses, mobile applications, and privacy. There are several benefits to using google classroom, including first, easy delivery, teachers can easily add students to join classes that have been created directly or share code with classes that join in just a few minutes, to access material delivery and assignments can also be easily made by teachers. Second, the simple flow of tasks and the absence of paper use enable teachers to make, check and assess assignments quickly in one place. Save time, Third, improve organization, students can easily access assignments on the assignment page and all existing material is automatically stored in the google drive folder. Fourth, improve communication, the use of google classroom makes it easy for teachers to make announcements and start discussions directly, besides students can share resources with each other or provide answers to questions that have been given. Fifth, affordable and safe, like most educational application services, classroom goggles do not contain advertisements, never use content.

The use of google classroom applications aims at learning will be more easily realized and full of meaningfulness. Therefore, the use of google classroom actually makes it easier for teachers to manage to learn and convey information precisely and accurately to students (Hakim, 2016). Through learning with blended learning, students feel comfortable and active in constructing their knowledge. Teachers can take advantage of various features found in google classroom such as assignments, grading, communication, time-costs, archive courses, mobile applications, and privacy. This research is also expected to provide a solution to the methods that have been applied in the classroom, namely by conventional methods where doses dominate learning activities both with the lecture method or the assignment method.

The use of electronic media certainly has positive and negative things, the positive thing that is obtained is that students do not collect papers in their assignments so that they become more efficient. Another thing, learning using e-learning is still not widely used in education, this is certainly an attraction for students so that they are more motivated in learning. However, the negative thing is that sometimes the use of e-learning media requires a fast network, this is very annoying when there is no network.

Here are some previous research on the use of google classroom, Nurhayati, Az-zahra, \& Herlambang (2019) researched e-learning with the results obtained from this study on the aspects of general usability, Edmodo found 9 problems and google classroom 12 problems. In the user experience aspect, Edmodo indicates the following code: (1) supports; (2) confusing; (3) complicated. As for google classroom, indicate the following code: (1) practical; (2) pleasant; (3) 
does not meet expectations; (4) confusing. The conclusion that can be formulated is, Edmodo is suitable for the learning process that uses e-learning fully, while google classroom is more suitable to be used as a support/complement of learning. Another research conducted by Rachmadyanti \& Wicaksono (2016) about google classroom with the results obtained from this study is the use of google classroom can provide access to students in learning online. The teacher can provide learning even if not in class. This is a form of teacher supervision of students when out of school. Furthermore, research on google classroom was also carried out by Aditya (2018) with the results of this study showing that the use of e-learning was able to increase the ability of English tutors in course institutions in terms of applying learning technology, specifically the use of google classroom in the classroom. From the results of these studies on the use of google classroom media, researchers want to determine the effectiveness of google classroom media on the learning outcomes of Madrasah Ibtidaiyah Teacher Education Department's Student UIN Syarif Hidayatullah Jakarta.

\section{METHODS}

The research method used is qualitative research with a case study approach that aims to examine the condition of objects naturally, researchers as key instruments in research. Data sources of this research include the words and actions of students and lecturers. Subjects of this research are students of Department of Madrasah Ibtidaiyah Teacher Education (PGMI) semester 2, 4, and 6. Data are taken from the activities of students and lecturers in lectures, where learning uses google classroom. Data sources in this study are all sources of information related to the use of google classroom media by students consisting of semesters 2, 3, and 6. Where they use google classroom as a medium in learning, sending assignments and receiving assessments by lecturers.

The main instrument in this study is the observation sheet and direct observation in the collection, completion, and analysis of research data. In addition to researchers as the main instrument, this study also uses supporting instruments to support research data in the form of student work sent to the Google classroom that has been made.

Data collection techniques in the data collection procedure in this study are the observation of participating and collecting documents related to the use of google classroom on learning. Data analysis using interactive models. In the context of testing the data reliability, the researcher will carry out the following activities: (1) continuous observation; (2) increase perseverance; and (3) data triangulation (Pransetyapri, Salim, \& Supriadi, 2013). 


\section{RESULTS AND DISCUSSION}

The application of google classroom according to some researchers and figures is one of the efforts to simplify and streamline time so that its use is expected to have implications for student learning outcomes. But in practice the use of google classroom is not so optimal, so researchers need to evaluate so that the application of this application is more optimal. Several studies conducted by Nurhayati, Az-zahra, \& Herlambang (2019), Anshari, Almunawar, Shahrill, Wicaksono, \& Huda (2017) and Aditya (2018) revealed that the use of e-learning applications (google classroom) can increase the effectiveness and activities of students.

In this study, researchers act as well as instructors in several subjects that will be sampled in this study, so that research can be done more effectively. Some of the subjects sampled in this study include Islamic Education in the 6th semester, Curriculum and Learning in the 2nd semester, Micro Teaching in the 6th semester and Learning Planning in 4 . The following lists the distribution of courses and the number of students:

Table 1. Course Tables using Google Classroom

\begin{tabular}{clcc}
\hline No & \multicolumn{1}{c}{ Course } & Semester & Total Students \\
\hline 1 & Ilmu Pendidikan Islam & 6 & 77 \\
2 & Kurikulum dan & 2 & 83 \\
& Pembelajaran & 6 & 15 \\
3 & Micro Teaching & 4 & 36 \\
4 & Perencanaan Pembelajaran & & \\
\hline
\end{tabular}

The table 1 above explains the distribution of courses using the Google classroom application conducted by researchers. In semester 6 there are courses in Islamic Education and Micro Teaching, totaling 77 and 15 students. Semester 2 Curriculum and Learning courses are consisting of 83 students and semester 4 Learning Planning courses are consisting of 36 Students.

In determine of effectiveness of the google classroom media, referring to the opinion expressed by Slavin (2019), that the effectiveness of learning is marked by several indicators, including 1) Quality of insurance, 2) Adherence to learning levels (an appropriate level of instruction), 3) Incentives and 4) Time. For this reason, in this study, the researcher referred to the 4 (four) indicators.

1) Quality of insurance

The quality of learning will greatly affect the objectives and learning outcomes produced. Besides, the quality of learning will be an attraction for students participating in learning. In the learning process, researchers used hybrid learning, which is a combination of face-to-face and online learning. Where researchers use google classroom online as a medium. The use of google 
classroom media is very helpful for lecturers in conducting learning interactions, because it can be done anywhere and anytime. So the quality of learning is getting better, it is marked by the activeness of students and lecturers in conducting learning communication. Researchers as lecturers give assignments to students on the google classroom page, students can directly access. The following tasks are given by researchers:

Table 2. Task for Islamic Education Subjects

\begin{tabular}{ccccc}
\hline No & Task & Given Away & Handed Over & Rated \\
\hline 1 & Book report & 8 & 15 & 54 \\
2 & Record of each meeting & 1 & 42 & 34 \\
3 & Observation report & 5 & 12 & 60 \\
4 & Book review & 34 & 43 & - \\
\hline
\end{tabular}

In the table 2 above, it can be seen that for one semester the researchers as lecturers gave several tasks, namely: book report, note of each meeting, observation report and book review. In each of these assignments there are several columns namely the assignment given, meaning the assignment given by the lecturer to students to be downloaded and done, if in that column there are still students who have not submitted it, it will be seen. The assignment is submitted, it indicates that the assignment given by the lecturer has been returned (the student has done it). Assignments are graded, this column indicates that assignments that have been submitted by students to lecturers have been graded. From the assignments given by the lecturer, students are more active in attending lectures, students must work on and send assignments if they want to be assessed by the lecturer. This is considered to improve the quality of learning because students and lecturers are more active.

If seen from the table 2 above, we can see, the level of students sending is greater, but there are still some students who don't send assignments. Researchers understand that the use of online electronic media is not all capable students well if we look at the table above there are still those who have not sent the amount is not proportional to the number of students who have sent. From this table, the researcher can assess that the number of assignments given by the total number of students in Islamic Education (IPI) courses is still not optimal. This has an impact on assessments given by lecturers to students, there are still some students who have not yet received grades. So that this becomes additional work by the lecturer, how can students get all grades? Of course, with additional assignments using assignments, such as making papers. The lecturers considered why there were still students who did not send assignments because they were still confused in using the google classroom media.

2) Appropriate level of instruction

From the tasks given by the lecturer, namely: notes of each meeting, Book report (book review), Observation report, review of educational books. The task of recording each meeting is 
expected that students can represent what has been said by the lecturer so that what the lecturer can convey can be understood by students. According to cognitive theory, what is seen, heard and recorded by someone will be remembered more than just being heard. Each student meeting has an individual responsibility to record what is conveyed during lectures. Book report (book review), students are expected to have one book that is truly mastered. The weakness of our students at the moment is lazy in reading, with the existence of this task it is hoped that it can foster the habits of students to get used to reading.

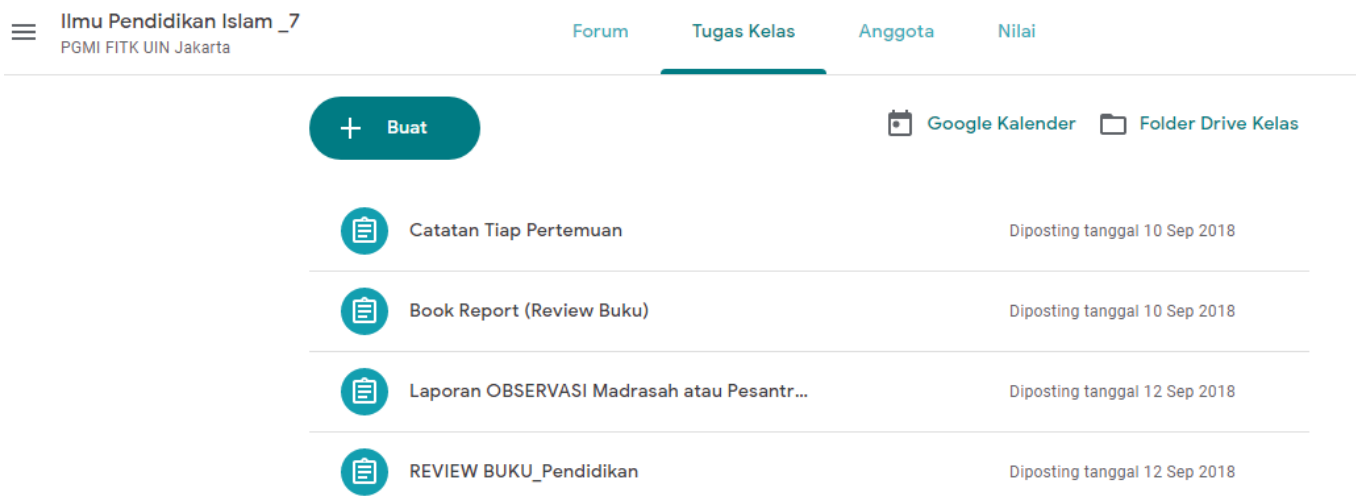

Figure 1. The activeness of students in fulfilling lecture assignments

In this study the intended target is students, so the use of google classroom online media is very appropriate to the level of learning. It can be seen from the ability of students to understand the use of the media by marking the majority of students who are active and respond to the assignments of the lecturers.

If you see the appropriateness of using the google classroom media on students it is certainly very appropriate, because in the industrial era 4.0 both teachers and students must be prepared to use online media. Most students have been able to take part in learning, therefore researchers conclude that learning using the google classroom media is practical and fun.

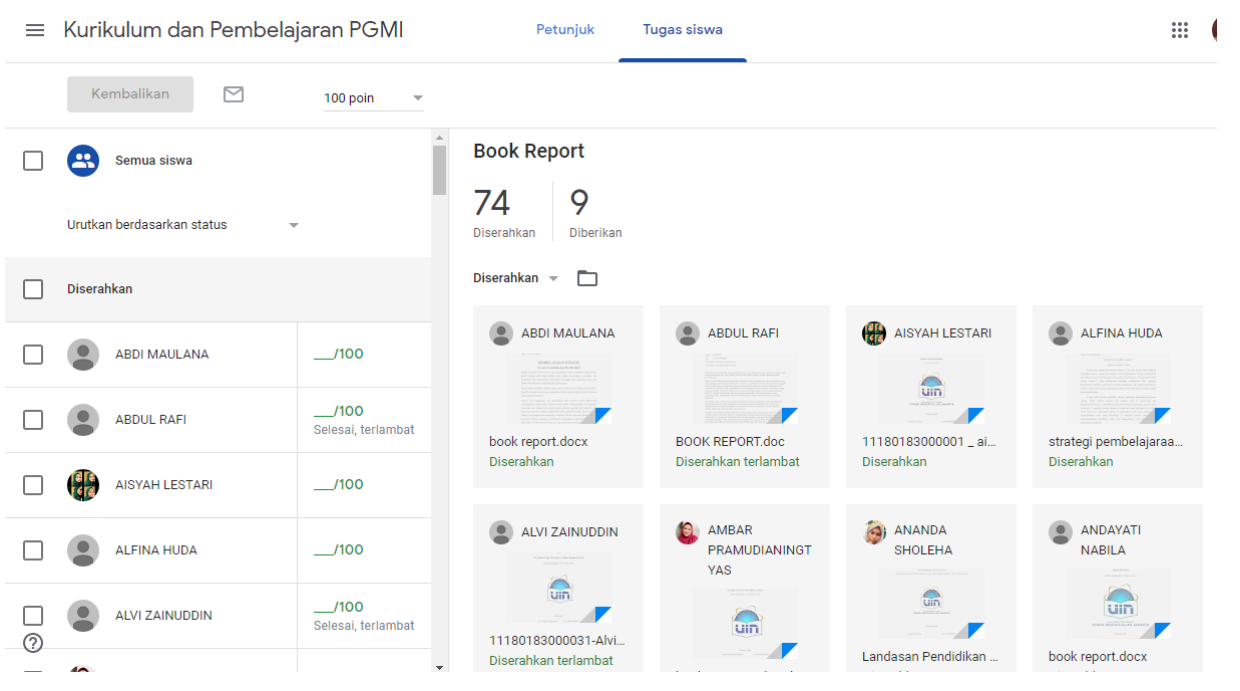

Figure 2. Data of student activity in lectures using google classroom 
3) Intensive

How much effort the lecturer has in motivating students to complete or work on assignments and study the material provided. The greater the motivation given, the greater the student's activeness so that learning will be effective. One of the motivations for learning to use google classroom is active lecturers in discussion forums, so students feel there is more attention given by lecturers. Learning using google classroom is learning that is not widely used by teachers, this is a means to foster students' interest in learning, after that they will be motivated in participating in learning.

The use of google classroom media can be done anywhere and anytime, as long as there is a strong network. So students have no reason because there is no cost to print assignments and so forth. The researcher concludes that learning using google classroom media is practical and economical.

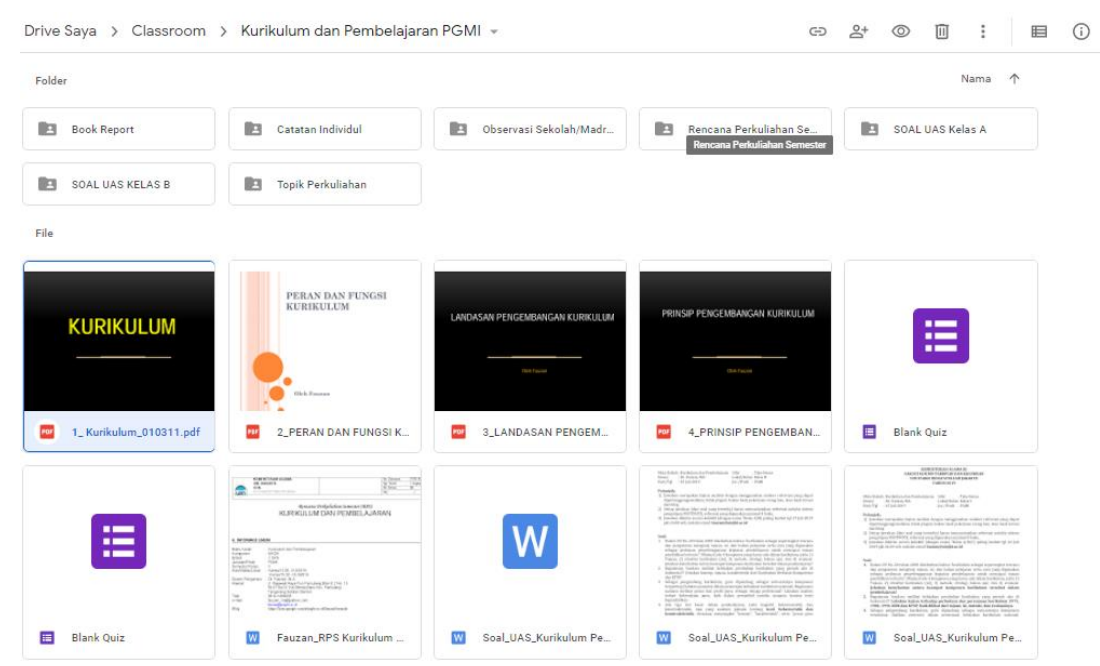

Figure 3. Data of student activity in lectures using google classroom

4) Time

The time here is how much time is needed to complete learning activities. Learning will be effective if students can complete the lessons by the specified time. In learning to use google classroom media, the time required is quite extensive, the lecturer gives a time limit for students to do their work, so that time is more effective for lecturers to do other assignments. For example, the assignment notes for each student meeting are given time before the next meeting, the review book is given one semester, and observations are given one week. 


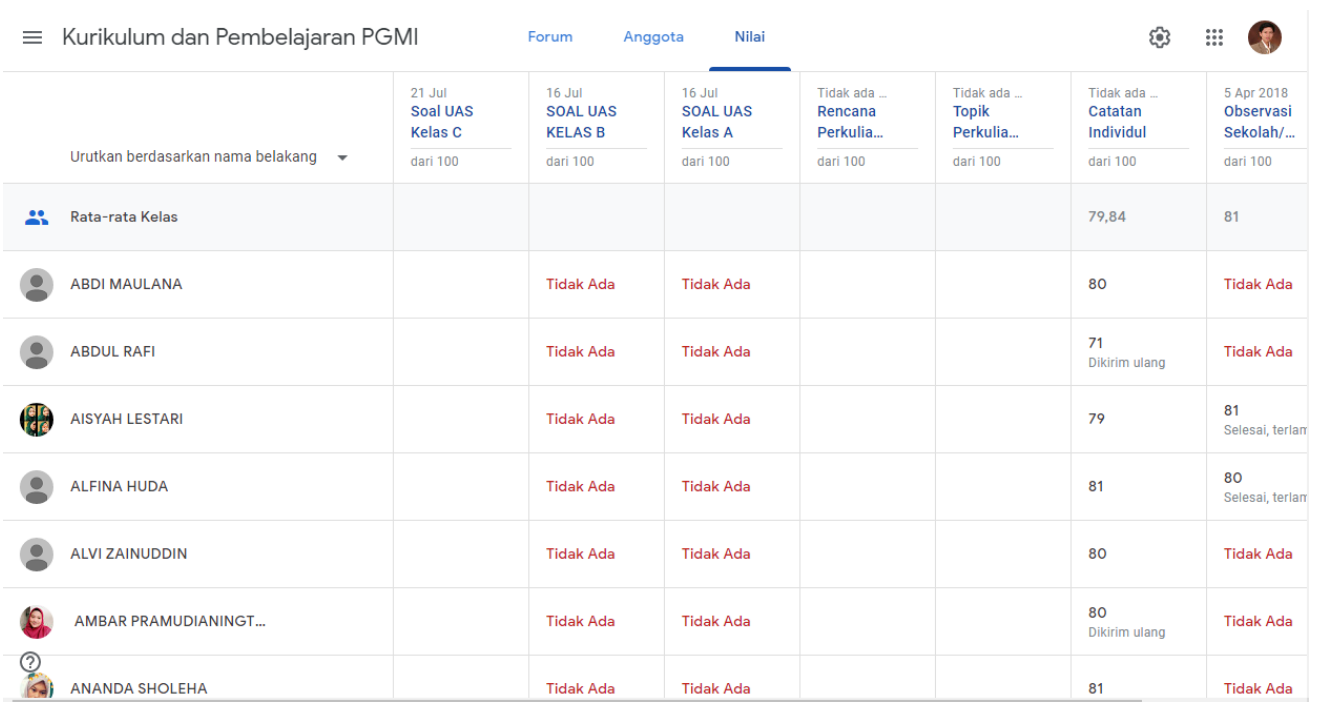

Figure 4. Data of student discipline in collecting assignments

From the results of the above research based on the results of previous studies that about the effectiveness and e-learning, some researchers conclude several research results related to the title, including research conducted by Huurun'ien, Efendi, \& Tamrin (2017) showing that the results of research related to the effectiveness of e-learning learning indicate that the use of elearning schoology based is more effective when compared to conventional learning, this can be shown by increasing the gain value of 0.94 and conventional learning by 0.74 . Furthermore, research related to the effectiveness of e-learning was also carried out by Islamiyah \& Widayanti (2016) who showed that learning using website-based e-learning was more effective than conventional learning, this was indicated by the results of the t-test namely $t$ count was smaller compared to t table $(3,516<1,725)$ means that $\mathrm{H}_{0}$ is rejected. Research conducted by Nadziroh (2017) suggests that the existence of a variety of e-learning systems makes students more independent and creative, but with a variety of e-learning systems not yet fully effective in improving learning. This is because the process of applying e-learning requires a stable internet connection and there is a need for comprehensive training of instructors to make the most of elearning.

When compared with these studies, the researcher himself assumes that the application of learning in practice is quite effective, but in theory, there are still many improvements that must be done. As an application that must be prepared even more carefully by researchers, so that no student is stuttering in using it. Gaps in the learning planning component The criteria for assessing google classroom learning planning indicators are the absence of commitment from the study program and lecturers as a whole to carry out this google classroom learning optimally, the learning process has not been directed at e-learning based learning (Sabran \& Sabara, 2004). The use of the google classroom application must be balanced with a good internet connection, this is often the reason for students when the assignments are given are often late because of a slow 
internet connection. Slavin suggested that learning would be effective if four indicators had been achieved, namely the quality of learning, the suitability of learning levels, incentives, and time. In this study, all four indicators have been achieved, so learning using the google classroom media is more effective.

\section{CONCLUSION}

Based on the results of research and discussion, it can be concluded that using google classroom media is effective. Conceptually, the use of google classroom media needs to be improved, so that the implementation can be maximized. In terms of quality of learning, using google classroom media is more effective and certainly fun, this is shown by the enthusiasm of students in participating in learning to use google classroom media. The level of intensity and time, the use of google classroom media is very practical and efficient because it can be used anywhere and anytime. So there is no reason for students to be late in sending assignments. Hopefully, this research on the use of the google classroom e-learning model can become an alternative learning media by teachers, because it is time in the era of industrial revolution 4.0, teachers and students can take advantage of the use of technology and information. So that learning is not monotonous done conventionally.

\section{REFERENCES}

Aditya, M. Y. (2018). Penerapan Google Classroom pada Pembelajaran Bahasa Inggris di Lembaga Kursus Bahas Inggris (E-Home dan Fun Learning) Kecamatan Bangkalan Kabupaten Bangkalan. Elpeduaem, 4(4), 15-18.

Alonso, F., López, G., Manrique, D., \& Viñes, J. M. (2005). An Instructional Model for Web Based E-Learning Education with a Blended Learning Process Approach. British Journal of Educational Technology, 36(2), 217-235.

Anshari, M., Almunawar, M. N., Shahrill, M., Wicaksono, D. K., \& Huda, M. (2017). Smartphones usage in the classrooms: Learning aid or interference?. Education and Information Technologies, 22(6), 3063-3079.

Ausubel, D. P. (1967). A cognitive structure theory of school learning. Instruction: Some contemporary viewpoints. San Francisco: Chandler.

Badriyah. (2015). Manajemen Sumber Daya Manusia. Bandung: Pustaka setia.

Bloom, B. S. (1973). Recent developments in mastery learning. Educational Psychologist, 10(2), 53-57.

Couse, L. J., \& Chen, D. W. (2010). A tablet computer for young children? Exploring its viability for early childhood education. Journal of research on technology in education, 43(1), 75-96.

Gagne, R. M. (1968). Contributions of learning to human development. Psychological review, 75(3), 177.

Gunawan, F. I. (2017). Pengembangan Kelas Virtual Dengan Google Classroom Dalam Keterampilan Pemecahan Masalah (Problem Solving) Topik Vektor Pada Siswa Smk 
Untuk Mendukung Pembelajaran. Prosiding Seminar Nasional Etnomatnesia, 340-348.

Hakim, A. B. (2016). Efektifitas Penggunaan E-Learning Moodle, Google Classroom dan Edmodo. I-STATEMENT, 2(1). 1-6

Hanum, N. S. (2013). Keefetifan e-learning sebagai media pembelajaran (studi evaluasi model pembelajaran e-learning SMK Telkom Sandhy Putra Purwokerto). Jurnal Pendidikan Vokasi, 3(1), 90-102.

Hardiyana, A. (2015). Implementasi Google Classroom sebagai Alternatif dalam Meningkatkan Mutu Pembelajaran di Sekolah. Karya Tulis Ilmiah, Cirebon: SMA Negeri, 1.

Heinich, R. (1984). The proper study of instructional technology. ECTJ, 32(2), 67-88.

Huurun'ien, K. I., Efendi, A., \& Tamrin, A. G. (2017). Efektivitas penggunaan E-Learning Berbasis Schoology DENGAN MENGGUNAKAN MODEL DISCOVERY LEARNING TERHADAP PRESTASI BELAJAR SISWA PADA MATA PELAJARAN SISTEM KOMPUTER KELAS X MULTIMEDIA SMK NEGERI 6 SURAKARTA PADA TAHUN PELAJARAN 2015/2016. Jurnal Ilmiah Pendidikan Teknik Kejuruan (JIPTEK), 10(2), 36-46.

Islamiyah, M., \& Widayanti, L. (2016). Efektifitas Pemanfaatan E-Learning Berbasis Website Terhadap Hasil Belajar Mahasiswa STMIK Asia Malang Pada Mata Kuliah Fisika Dasar. Jurnal Ilmiah Teknologi Informasi Asia, 10(1), 41-46.

Kurnia, N., Darmawan, D., \& Maskur, M. (2018). Efektivitas Pemanfaatan Multimedia Pembelajaran Berbantuan Ispring Dalam Meningkatkan Motivasi Dan Hasil Belajar Pada Mata Pelajaran Bahasa Arab. Teknologi Pembelajaran, 3(1).

Kusmana, A. (2017). E-learning dalam Pembelajaran. Lentera Pendidikan: Jurnal Ilmu Tarbiyah dan Keguruan, 14(1), 35-51.

Nadziroh, F. (2017). Analisa Efektifitas Sistem Pembelajaran. Jurnal Ilmu Komputer dan Desain Komunikasi Visual, 2(1), 1-14.

Nurhayati, D., Az-zahra, H. M., \& Herlambang, A. D. (2019). Evaluasi User Experience Pada Edmodo Dan Google Classroom Menggunakan Technique for User Experience Evaluation in E-Learning (TUXEL) ( Studi Pada SMKN 5 Malang ). Jurnal Pengembangan Teknologi Informasi dan Ilmu Komputer.

Pavlov, I. P., \& Gantt, W. H. (1941). Conditioned reflexes and psychiatry (Vol. 2). New York: International publishers.

Pransetyapri, S. E., Salim, I., \& Supriadi, S. (2013). ANALISIS EFEKTIVITAS PEMBELAJARAN SOSIOLOGI PADA SISWA KELAS X DI MADRASAH ALIYAH AL-ANWAR PONTIANAK. Jurnal Pendidikan dan Pembelajaran, 7(8).

Rachmadyanti, P., \& Wicaksono, V. D. (2016, August). Pendidikan Kewirausahaan bagi Anak Usia Sekolah Dasar. In Prosiding Seminar Nasional Inovasi Pendidikan.

Rohmawati, A. (2015). Efektivitas Pembelajaran. Jurnal Pendidikan Usia Dini, 9(1), 15-32.

Rozak, A., \& Albantani, A. M. (2018). Desain Perkuliahan Bahasa Arab Melalui Google Classroom. Arabiyat: Jurnal Pendidikan Bahasa Arab Dan Kebahasaaraban, 5(1), 83102.

Sabran, \& Sabara, E. (2004). Keefektifan Google Classroom sebagai media pembelajaran. Diseminasi Hasil Penelitian Melalui Optimalisasi Sinta Dan Hak Kekayaan Intelektual, $122-125$.

Seels, B. B., \& Richey, R. C. (2012). Instructional technology: The definition and domains of the 
field. IAP.

Signe, N., \& Rikke, Ø. (2015). The Effectiveness of E-Learning: An Explorative and Integrative Review of the Definitions, Methodologies and Factors that Promote e-Learning Effectiveness ResearchLAB : IT and Learning Design, Dep . of Learning and Philosophy , Aalborg. The Electronic Journal of E- Learning, 13(4), 278-290.

Skinner, B. F. (1950). Are theories of learning necessary?. Psychological review, 57(4), 193.

Slavin, R. E. (2019). Educational psychology: Theory and practice.

Soni, S., Hafid, A., Hayami, R., Fatma, Y., Wenando, F. A., Al Amien, J., \& Hasanuddin, H. (2018). OPTIMALISASI PENGGUNAAN GOOGLE CLASSROOM, E-LEARNING \& BLENDED LEARNING SEBAGAI MEDIA PEMBELAJARAN BAGI GURU DAN SISWA DI SMK NEGERI 1 BANGKINANG. Jurnal Pengabdian UntukMu NegeRI, $2(1), 17-20$.

Suharyanto, S., \& Mailangkay, A. (2016). Penerapan E-learning sebagai Alat Bantu Mengajar dalam Dunia Pendidikan. Jurnal Ilmiah Widya, 3(4), 17-21.

Susilo, F. A. (2013). Peningkatan Efektivitas Pada Proses Pembelajaran. MATHEdunesa, 2(1).

Undang-undang nomor 20 Tahun 2003 tentang Sistem Pendidikan Nasional

Walter, C., \& Briggs, J. (2012). What professional development makes the most difference to teachers. A report sponsored by Oxford University Press. Retrieved on July, 20, 2015.

Yazdi, M. (2012). E-Learning Sebagai Media Pembelajaran. Jurnal Ilmiah Foristek, 2(1), 143152.

Zakaria, E., \& Salleh, F. (2012). Teachers' Creativity in Posing Statistical Problems from Discrete Data. Creative Education, 3(8), 1380-1383. 